\title{
Assessment of Knowledge Sharing Practices in Nigerian Construction Firms
}

\author{
Mohammed Alhaji Kasimu ${ }^{1}$, Mohammed Isah Leje ${ }^{2}$
}

${ }^{1}$ The Federal Polytechnic, Bida

KM 1.5, Doko Road, Bida, Niger State, Nigeria

DOI: $10.22178 /$ pos.51-4

LCC Subject Category: H1-99

Received 10.09.2019

Accepted 09.10.2019

Published online 31.10.2019

Corresponding Author:

Mohammed Alhaji Kasimu

isahleje5@yahoo.com

(c) 2019 The Authors. This article

is licensed under a Creative Commons

Attribution 4.0 License @) (1)

\begin{abstract}
Knowledge generated during construction projects is wasted as a result of a lack of awareness of the benefits of sharing knowledge. Moreover, knowledge is scattered in the construction firms through various documents and individual brains without a platform to retrieving it for sharing among the employees. Therefore, this paper aims to assess knowledge sharing practices in Nigerian construction firms. A detailed review of relevant literature was conducted with the view of collecting relevant data necessary for this paper. A total of 150 numbers of questionnaires was distributed to Engineers, Quantity surveyors, Builders and Architects in construction firms that are based in Abuja. The descriptive method of analysis was used to analyze the data obtained from the survey. The result shows the followings as methods of knowledge sharing practices in Nigerian construction firms: (1) face to face interaction, (2) site \& Departmental meetings, (3) mentoring and tutoring, (4) project briefing and interviewing session, and (5) internal training courses. In addition, the followings were established as construction activities that are commonly used for knowledge-sharing practices: (1) site visitation, (2) estimation \& price forecasting, (3) evaluation of BOQ, (4) preparation of scheduling for site activities, (5) development of tender programme, (6) taking off and (7) understanding of construction technologies and methods. Therefore, the paper recommended that the top management should encourage knowledgesharing practices in the construction firms through face to face interaction, seminars/workshops, and post-project review.
\end{abstract}

Keywords: construction firms and construction projects; knowledge; knowledge management and knowledge sharing.

\section{INTRODUCTION}

Knowledge sharing across a project is vital since the knowledge transfer from a current to concurrent or subsequent projects allows employees to use existing proven knowledge to solve problems as a substitute for creating new knowledge, which can guzzle time [17, 40]. Author [46] asserted that when an organization has deficiencies in a heightened degree of knowledge sharing, knowledge leaks are the consequences. Therefore, such leakage ultimately results in organizational inefficiency like repeated mistakes, depending on a few key individuals, duplicated work, lack of sharing of good ideas, and slows in the adoption of new ideas, techniques, and technical know-how and problems solutions. Researches [50] further expressed that knowledge sharing is the heart of knowledge management (KM) practice. If professionals do not share what they know, then there is generally a little knowledge to be managed. This was supported by [37] that, the concept of KM is to create a knowledgesharing atmosphere whereby "knowledge sharing is power," as opposed to the ancient belief that "knowledge is power. The construction firms in Nigeria are still being criticized for continuous mistakes and errors during the construction phase of the projects, dispute, poor planning and design, time and cost overruns and poor quality of workmanship [31]. This reflects that knowledge and professional experiences are not shared among the employees for re-use. This lack of knowledge sharing practice in Nigerian construction firms has been a serious challenge in developing countries like Nigeria. Therefore, the 
above-mentioned gap is the motivating factor for this study to establish the methods of Knowledge sharing practices in Nigerian construction firms. And identify the construction activities that are commonly used for knowledge sharing practices in Nigerian construction firms.

Knowledge Sharing in the Construction Firms. Construction firms involve construction professionals with different backgrounds of knowledge working jointly to produce the products of these firms by contributing their knowledge and experiences to actualize the dreams of these firms as well as clients [30]. This situation provides the employees with the opportunity to gain knowledge and professional experiences to accomplish the project task. Authors [7] further stated that the procedure of the construction projects provides the employees with the opportunity to adhere to the practice of problemsolving in the construction project setting, acquiring and developing knowledge by applying different sources. In the execution of the construction project, the organizations in the construction industry as compared to other industry used project knowledge to improve the new technology and innovation. Authors [38] emphasized that construction projects can be separated from its context, like the historical background and organizational location. Authors emphasized that sharing knowledge and professional experiences within the construction firms has become a challenge depending on informal and personal relationships. $\mathrm{KM}$ initiatives have commonly been concentrating on capturing, codifying and transferring knowledge [3, 18, 28]. Capturing knowledge and mediating it across organizational boundaries is dependent on roles that support, connect projects and organizations [5, 36]. Mediating knowledge has been usually in line with the support of functions and domain experts who have been found to rely on personal contacts to perform the task [5, 29].

Knowledge sharing (KS) within the construction firms is vital, as it certainly leads to knowledge application, innovation, as well as a competitive advantage for the construction firms [2, 13, 25]. However, $80 \%$ of valuable knowledge is tacit and cannot be written down. KM policy and strategies have to accept this fact and plan for way forward [48]. KS has the maximum value within the construction firms, knowledge is shared and retailed in a means that encapsulate the professional experiences and characteristic that elevates the data and information to knowledge [43]. KS enables the training curve of the recipient to accelerate once it has become the approach and system of the construction firms [49]. Authors [27] conducted a study on KS mechanisms for different types of knowledge and they observed that employees learned fairly well on how to share explicit knowledge. And further suggested that it will be better if workers can be encouraged in sharing tacit knowledge, where the process of knowledge transfer and innovation will significantly speed up. However, the KS mechanism was summarized in Table 1.

Table 1 - The knowledge sharing mechanism

\begin{tabular}{|l|l|l|l|l|}
\hline No & \multicolumn{1}{|c|}{$\begin{array}{c}\text { Types of } \\
\text { Knowledge }\end{array}$} & \multicolumn{1}{c|}{$\begin{array}{c}\text { Method of } \\
\text { Access }\end{array}$} & \multicolumn{1}{|c|}{ Sharing Mechanism } & \multicolumn{1}{|c|}{ Media } \\
\hline 1 & $\begin{array}{l}\text { Systematic } \\
\text { knowledge }\end{array}$ & Research model & $\begin{array}{l}\text { Computer imitation, scenario } \\
\text { planning }\end{array}$ & System tools \\
\hline 2 & Tacit knowledge & Practice & $\begin{array}{l}\text { Brainstorming } \\
\text { system }\end{array}$ & $\begin{array}{l}\text { Publications } \\
\text { presentation }\end{array}$ \\
\hline 3 & Explicit knowledge & $\begin{array}{l}\text { Listening } \\
\text { \&Reading }\end{array}$ & Communication & Intelligence Model \\
\hline 4 & Hidden knowledge & Socialisation & Focused groups & Social setting \\
\hline 5 & $\begin{array}{l}\text { Relationship } \\
\text { knowledge }\end{array}$ & Interaction & Partnership, teamwork & \\
\hline
\end{tabular}

Source: [30]

According to [33] KS is the activity of transmitting or sharing knowledge among the employees of the construction firms. KS is described as the procedure through which employees of the con- struction firms mutually exchange their knowledge, skills, past experiences and collectively generate new knowledge and innovation within the firms [39]. KS is accomplished with the inter- 
actions and conversion between tacit and explicit knowledge as suggested by Nonaka are as follows: socialization, externalization, combination, and internalization, which facilitated the KS within the construction firms [10, 32, 41]. KS relies on the mutual understanding and respect of the employees. Authors [18] argued that KS is really a process of communication among the employees of construction firms. Knowledge is not like other goods that may concede anywhere easily; it is associated with a knowing subject. KS encompasses the relationship between a minimum of two parties, in which one offers knowledge and the other one acquires knowledge. Some researchers outlined that construction firms should produce a favorable atmosphere for KS $[16,52]$. They added that KS differs from information sharing for the reason that KS requires not only interacting the data to another party, KS includes enhancing the other party to comprehend the items in the information conveyed and gain knowledge from the information to rebuild the information into their own knowledge.

Based on the explanation and the views of the above previous researchers, this paper deduced and demonstrate the knowledge sharing practices in the construction firms as shown in Figure 1.

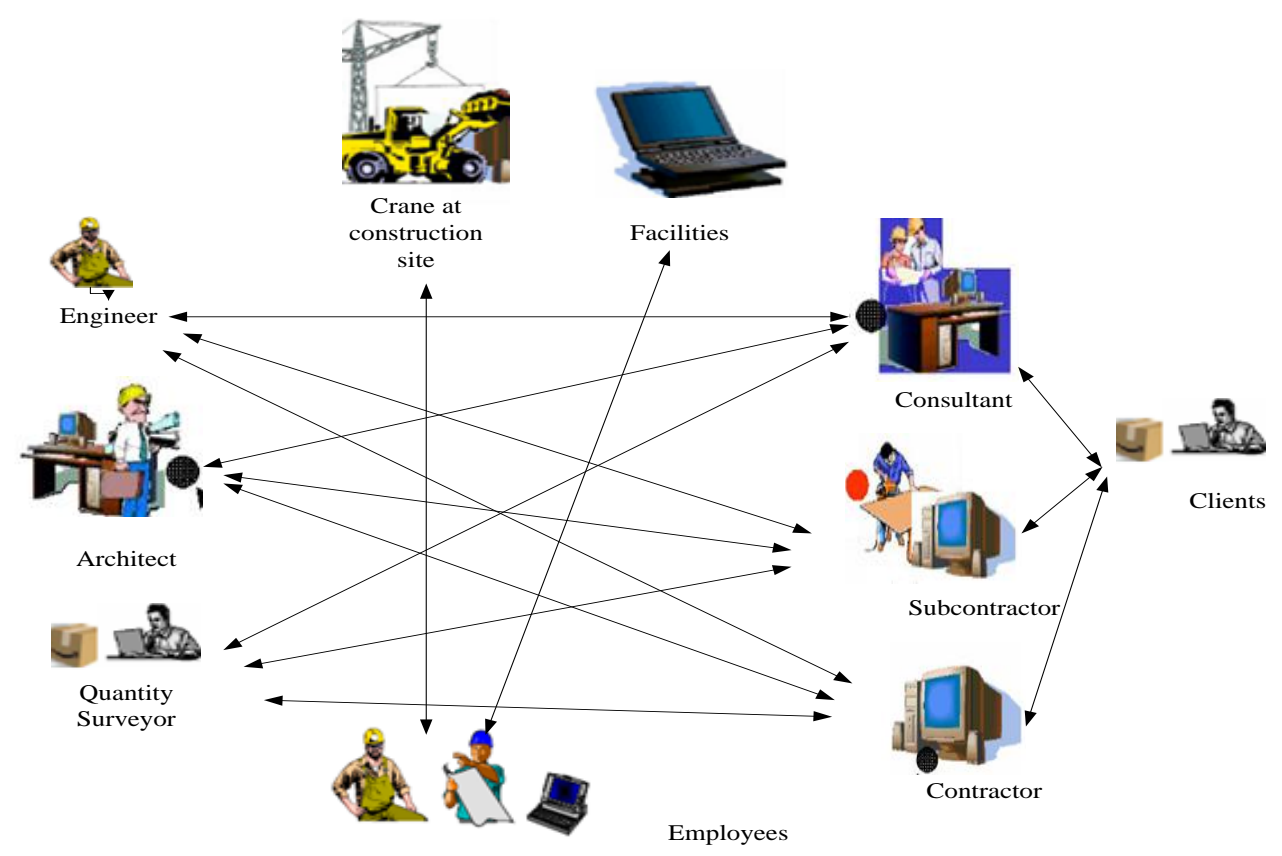

Figure 1 - Knowledge sharing practices in construction firms

The Influence of Organisational Culture on Knowledge Sharing. The organizational culture reflects the deep fundamentals that construction firms are dependent on such as their values, beliefs, background, and traditions [46]. Culture is an extremely wide concept and comprises many facets; one cultural aspect that is crucial for KS is a collaboration because KS requires employees to have social interaction and the exchange of ideas, views, and perceptions [53]. The attitudes towards KS are developing within the construction firms and extrinsically to the construction firms in the larger industry are significant. Certainly, knowledge is commonly seen by employees as a source of their advantage in the organization and thereby affected the employee willing to share knowledge [25, 34]. Many researchers discov- ered that cultural barriers that exist may hamper the implementation of the effective KS strategy and learning approaches within the construction firms [14, 15, 21, 45, 40]. Authors [7] conducted a study and discovered that cultural factors affect the knowledge transfer process. There is a need to establish organizational culture and senior management commitment and support to improve the incentive and reward systems for the employees to practice KS $[4,6]$.

Construction firm. A firm in a common word is an organization that carries together with the various factors of production, for example, labor, land, and capital to produce a product or facility that is anticipated to be sold for a profit or personal use [42]. Author [23] regarded firms as the 
planned organization of collective events of a group of people seeking to accomplish a common aim or set of goals. Interpreting in the context of construction, [47] stated that contractor sells their skills to assemble structures, the management services required to syndicate manpower, machinery, and material into new construction projects. The output of construction firms can be perceived as a service rather than a product [22, 35].

Different professional firms possess different creative skills and management skills that are essential to construction firms. These skills are in four dimensions, namely: the client, the technology to find a product, the transaction kind, and the project size and difficulty [26]. For example, some construction firms practice specialization according to their customers rather than products with a defined base of major customers.

\section{METHODS}

This study adopted a quantitative research approach via a survey questionnaire to sample individuals from a population to make statistical inferences about the population using the sample [11]. And also to pull out public opinion, such as beliefs, perceptions, ideas, views and thought about the knowledge sharing practices in Nigerian construction firms. To obtain the required population for this study, the stratified random sampling technique was adopted for the selection of the construction firms that participated in this study. This selection was in line with the concept of [12] that respondents are arranged in strata for the conveniency in questionnaire distribution and assessment. Also, the simple random sampling was adopted in each of the construction firms for the selection of construction professionals from the strata.

The questionnaire that was used to record the responses of each respondent contained mainly closed-ended questions using a five-point Likert scale ranged from very high, high, slightly high, low and none. The scores of the respondents were computed based on the variables used in the questionnaire. As earlier explained that simple random sampling techniques were adopted in each of the construction firms for the selection of construction professionals. 150 numbers of professionals were selected in Nigerian construction firms that are based in Abuja. These professionals are Quantity Surveyors forty numbers (40), Architects forty numbers (40), Builders forty numbers (40) and Civil Engineers thirty numbers (30). However, one hundred and forty (140) numbers of those selected professionals were able to return the questionnaire, while four (4) of the one hundred and forty (140) were ignored for incorrect entry.

The inference statistic was adopted to summarise the sample, rather than use the data to learn about the population and sample. In this paper, the inference statistic was used to present means score, standard deviation, and frequency counts. The mean score was used to rank the respondents' opinions or responses obtained.

\section{RESULTS AND DISCUSSION}

The age groups of the respondents. The age group of the respondents is analyzed and the result is presented in Figure 2. The result shows that $36.36 \%$ of the respondents are within the age group of 26-35 years old. Whereas $30.36 \%$ of the respondents are within the age group of 36-45 years, and $15.02 \%$ of the respondents are within the age group of 18-25 years. This result shows that the employees are within the age of 18-45 years. This reflects that the employees of Nigerian construction firms are within the active age to learn, share and acquire knowledge to improve the organizational performance.

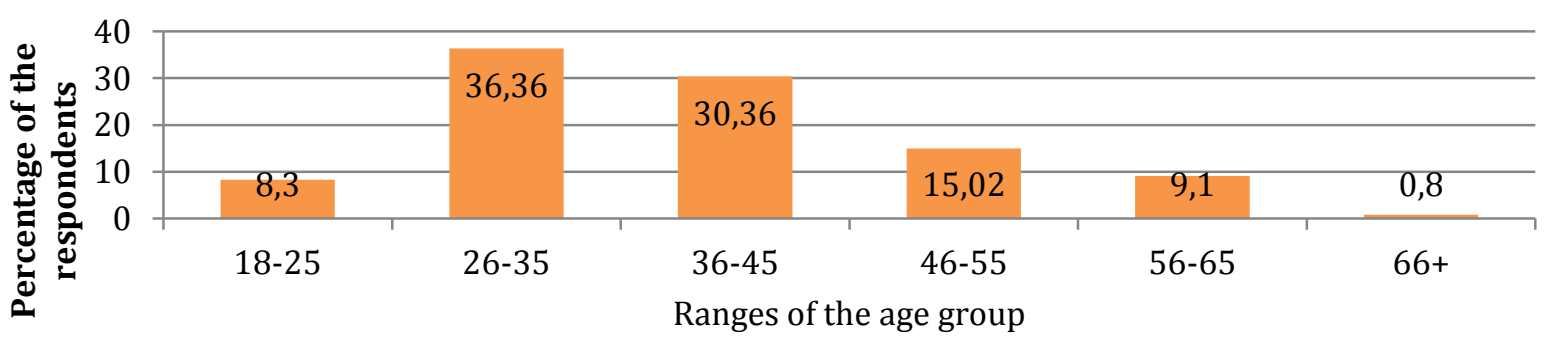

Figure 2 - The age group of the research respondents 
The educational background of the respondents. The respondents of this study specialize in different areas of professions such as Engineers, Quantity Surveyors, Architects, and Builders. These professionals obtained their knowledge and training skills in the above areas of specialization as mentioned. The professionals obtained certificates in these areas, but the nature of the certificates varies. The natures of the certificates obtained by the respondents are analyzed using descriptive analysis and the results are presented in Figure 3. The result shows that 34.39\% hold a Bachelor's degree in science (BSc), $31.62 \%$ hold a Higher National Diploma (HND). $18.18 \%$ hold a National diploma. $13.83 \%$ hold a Master of Science (MSc) degree and $1.98 \%$ holds a Doctor of Philosophy (Ph.D.). This implies that the respondents have the required educational training in line with the experiences acquired during the construction phase of the projects.

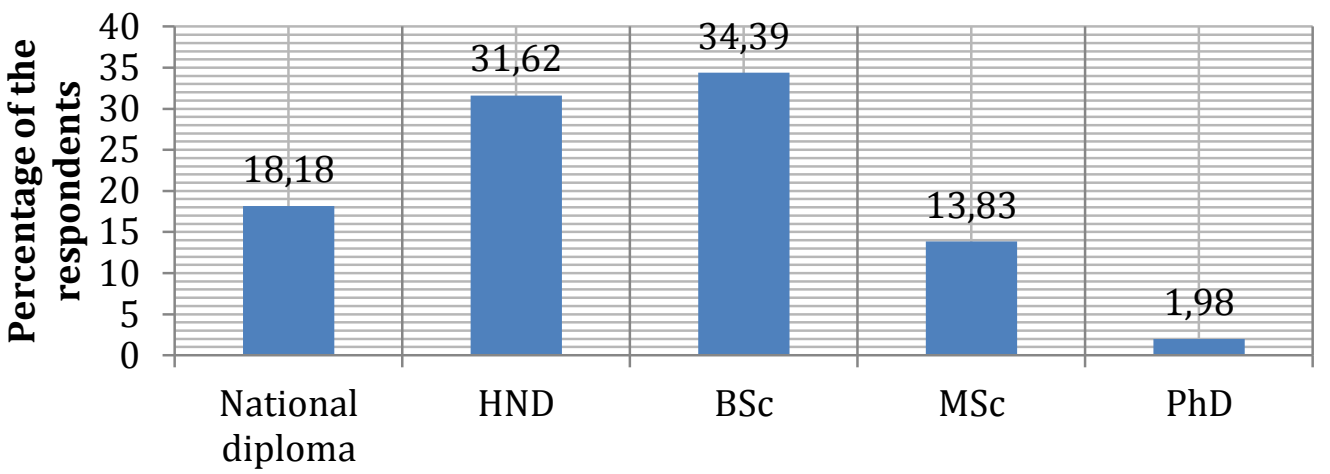

Level of educational qualification

Figure 3 - The educational qualification of the respondents

The respondent's working experiences. Figure 4 shows that $42 \%$ of the respondents are within the range of 6-10 years of working experiences. $24 \%$ of the respondents are within the range of 11-15 years of working experiences, $22 \%$ of the respondents are within the range of 1-5 year of working experiences and $9 \%$ of the respondents are within the range of 16-20 years of working experiences respectively. This shows that the respondents have adequate knowledge of construction projects based on their experiences.

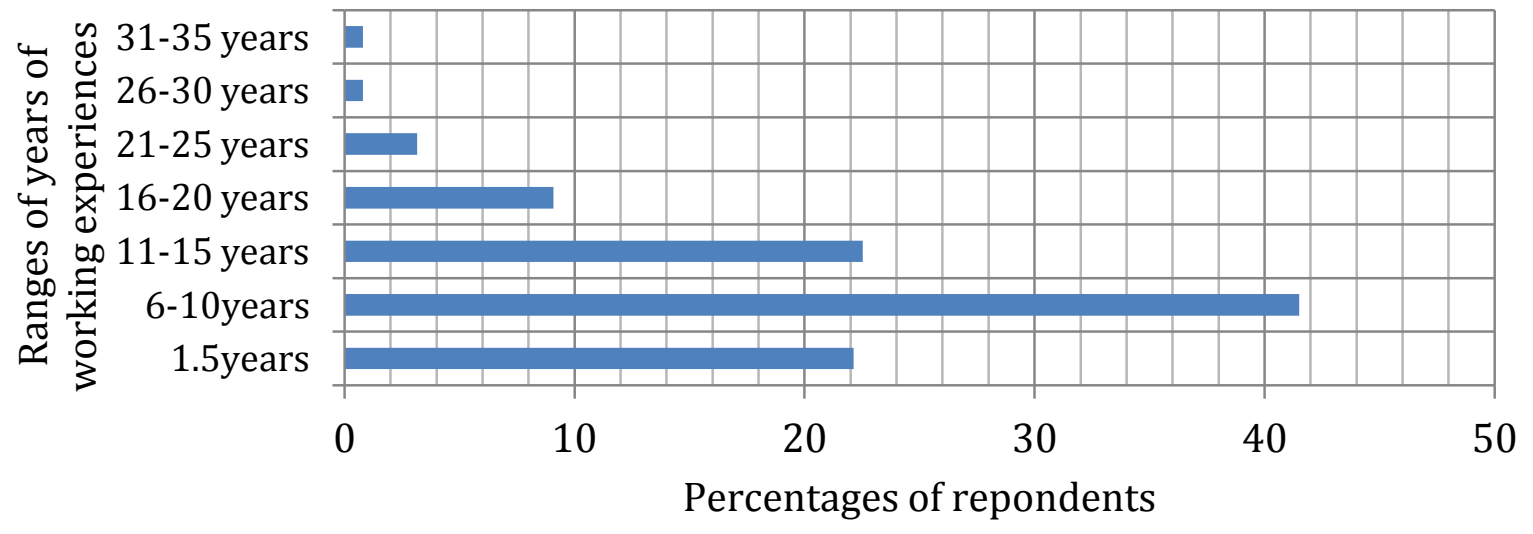

Figure 4 - The respondent's years of working experiences

The nature of the issues discussed during the knowledge sharing practice. Figure 5 shows $32 \%$ of the respondents admitted that the nature of the issues discussed during the period of sharing knowledge is issues concerning new works, methods, and technical issues. $28.5 \%$ of the respondents stated that the natures of the issues discussed are company news and new technology. This implies that the nature of issues discussed when sharing knowledge during construction projects are very essential since there are issues that bring innovation and improves organizational efficiency and performance. 


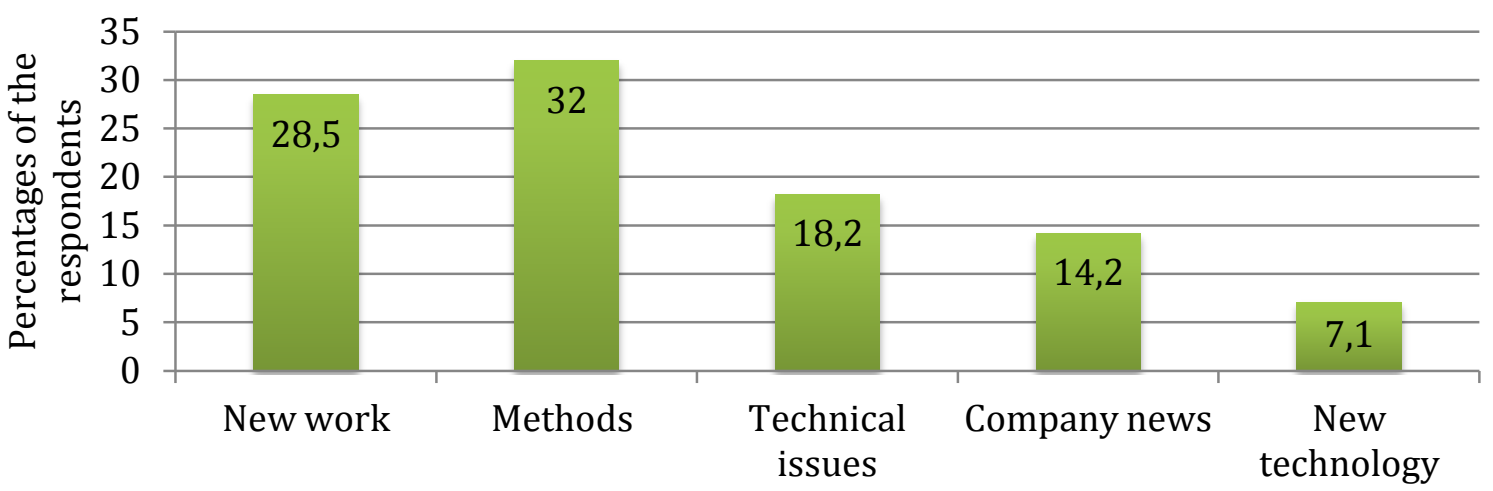

Figure 5 - The nature of the discussions

The level of knowledge sharing practices in Nigerian construction firms. The result from Figure 6 shows that $62.5 \%$ of the respondents do not practice knowledge sharing to solve the problems during the course of construction projects. However, 37.5 of the respondents acknowledged that they practice knowledge sharing during the courses of construction projects, especially when new staffs were employed and during the course of variations, errors, mistakes and reworks This reflects that knowledge sharing practices in $\mathrm{Ni}-$ gerian construction firms is still at infancy stage.

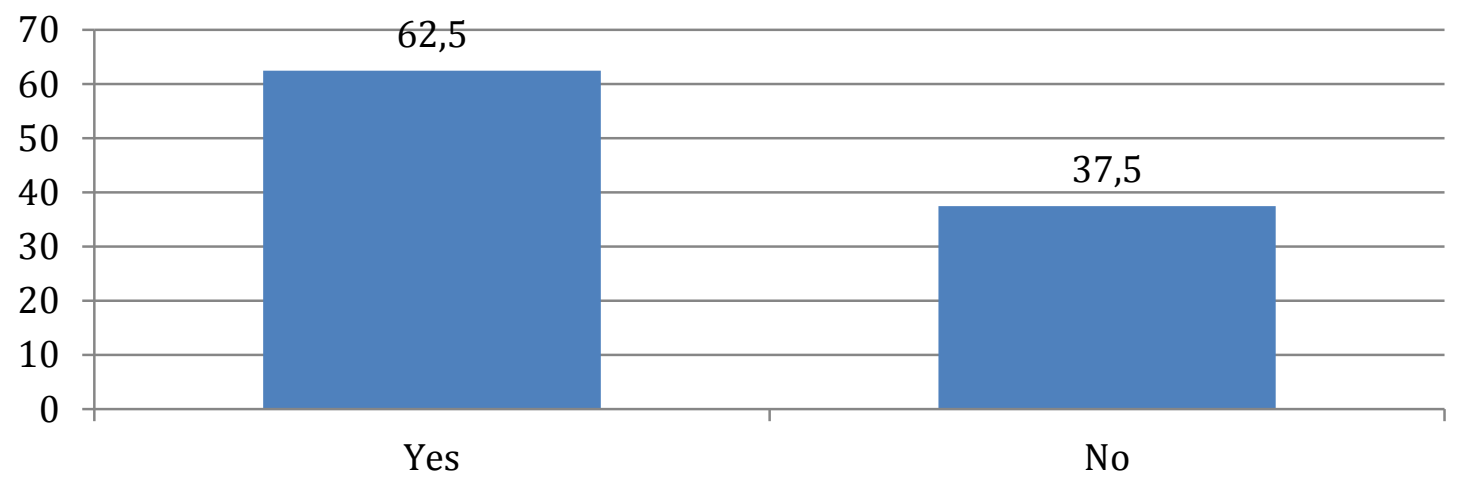

Figure 6 - Level of knowledge sharing practices in Nigerian construction firms, \%

The activities of construction projects that are commonly used for KS practice. The activities of construction projects that are commonly used for knowledge sharing were examined in Table 2 as shown below.

Table 2 shows the following as the main construction activities that are commonly used for knowledge sharing practices in Nigerian construction firms. These activities are site visitation, estimating and price forecast, evaluation of BOQ returned by the subcontractors, preparation of schedules for the site activities, development of the tender program, taking off, understanding construction technologies and methods, decision making on bids, bidding strategies and evaluation of tender documents.

These aforementioned construction activities were ranked 1-10 with the mean scores of the following 4.19, 3.99, 3.94, 3.92, 3.91, 3.90, 3.87 and 3.85 respectively. This indicates that the above-mentioned construction activities are mostly used for knowledge sharing practices in Nigerian construction firms.

Authors [24] agreed with the findings that knowledge is share based on the activities of each organization especially in the construction firm's where knowledge is shared in construction activities such as method and technologies used in construction, site visitation, bidding strategies and preparation of schedules and materials, etc.

Authors [20] conducted a similar study in Quantity Surveying firms in Malaysia and agreed with the findings by outline the followings construction activities used in knowledge sharing practices such as taking off, preparation of valuation certificate/report, project monitoring, site visitation, estimating and price analysis, examination of BOQ bidding strategies and contract administration. 
Table 2 - Activities of the construction projects used for KS

\begin{tabular}{|l|l|l|l|}
\hline $\begin{array}{c}\text { Construction activities } \\
\text { used for knowledge } \\
\text { sharing }\end{array}$ & Mean & $\begin{array}{c}\text { Std. } \\
\text { Deviation }\end{array}$ & Ranks \\
\hline Site visitation & 4.19 & 0.982 & 1 \\
\hline $\begin{array}{l}\text { Estimating and price } \\
\text { forecasting }\end{array}$ & 3.99 & 1.100 & 2 \\
\hline $\begin{array}{l}\text { Evaluation of BOQ } \\
\text { returned by the } \\
\text { subcontractors. }\end{array}$ & 3.94 & 1.167 & 3 \\
\hline $\begin{array}{l}\text { Preparing the schedules } \\
\text { for the site activities }\end{array}$ & 3.92 & 1.161 & 4 \\
\hline $\begin{array}{l}\text { Development of tender } \\
\text { programme }\end{array}$ & 3.91 & 1.142 & 5 \\
\hline Taking off & 3.91 & 1.200 & 6 \\
\hline $\begin{array}{l}\text { Understanding } \\
\text { construction technologies } \\
\text { and methods }\end{array}$ & 3.91 & 1.198 & 7 \\
\hline Decision making on bids & 3.90 & 1.147 & 8 \\
\hline Bidding strategies & 3.87 & 1.140 & 9 \\
\hline $\begin{array}{l}\text { Evaluation of tenders } \\
\text { documents }\end{array}$ & 3.85 & 1.198 & 10 \\
\hline $\begin{array}{l}\text { Understanding other } \\
\text { competitors }\end{array}$ & 3.82 & 1.104 & 11 \\
\hline $\begin{array}{l}\text { Participating in contract } \\
\text { administration }\end{array}$ & 3.79 & 1.257 & 12 \\
\hline Preparing specification & 3.78 & 1.324 & 13 \\
\hline $\begin{array}{l}\text { Choosing subcontractors } \\
\text { and suppliers }\end{array}$ & 3.51 & 1.382 & 14 \\
\hline
\end{tabular}

Source: Field work, (2019)

Methods of knowledge sharing practice in Nigerian construction firms. The methods of KS practices in Nigerian construction firms were examined and the findings from the analysis are presented in Table 3 below.

Table 3 shows the following as main methods of knowledge sharing practices in Nigerian construction firms: face to face interaction, site \& departmental meeting, mentoring and tutoring, project briefing and interview session and internal training courses. These methods mentioned above were ranked 1-5 with a mean score of $4.44,4.03,4.03,3.89$ and 3.82 respectively. This indicates that the aforementioned are the foremost methods of knowledge sharing practices in Nigerian construction firms.

Also, the followings are methods of knowledge sharing practices: post-project review, informal chatting, and storytelling, e-mail and internet were ranked 9-12 with a mean score of 3.23, $3.04,2.61$ and 2.42 respectively.
Table 3 - The methods of KS practice

\begin{tabular}{|l|l|l|l|}
\hline \multicolumn{1}{|c|}{ Methods } & Mean & $\begin{array}{c}\text { Std. } \\
\text { Deviation }\end{array}$ & Ranks \\
\hline Face to face interactions & 4.44 & 0.686 & 1 \\
\hline $\begin{array}{l}\text { Site meeting and dept. } \\
\text { meeting }\end{array}$ & 4.03 & 0.909 & 2 \\
\hline Mentoring and tutoring & 4.03 & 0.942 & 3 \\
\hline $\begin{array}{l}\text { Project briefing and } \\
\text { interviewing sessions }\end{array}$ & 3.89 & 1.016 & 4 \\
\hline Internal training courses & 3.82 & 1.119 & 5 \\
\hline $\begin{array}{l}\text { Talks, seminars and } \\
\text { workshops }\end{array}$ & 3.44 & 1.189 & 6 \\
\hline Database system & 3.42 & 1.329 & 7 \\
\hline $\begin{array}{l}\text { Phone calls and } \\
\text { teleconferencing }\end{array}$ & 3.41 & 0.966 & 8 \\
\hline Post projects review & 3.23 & 1.069 & 9 \\
\hline $\begin{array}{l}\text { Informal chatting and } \\
\text { story telling }\end{array}$ & 3.04 & 1.149 & 10 \\
\hline Through e-mail & 2.61 & 1.185 & 11 \\
\hline Through internet & 2.42 & 1.119 & 12 \\
\hline
\end{tabular}

Source: Fieldwork, (2019).

This signifies that the above mentioned are considered least methods of KS practices in Nigerian construction firms. Authors [9, 51] both conducted a similar study in Malaysia academic institutions and agreed with findings that the followings are a method of sharing knowledge in academic institutions such as face to face interaction, tutoring/lecturing, workshop/seminars, inhousing training, and informal chatting \& storytelling. Authors $[1,44]$ concord with the findings that method of knowledge sharing practices are mentoring, tutoring, coaching, seminars/workshop, physical interaction, internal training and through the internet.

\section{CONCLUSION}

This paper sort to assess the knowledge sharing practices in Nigerian construction firms to establish the method of sharing knowledge and construction activities used in knowledge sharing practices. Thus, the paper was able to establish the construction activities that are commonly used for knowledge sharing practices in Nigerian construction firms. These are (1) site visitation, (2) estimation and price forecasting, (3) evaluation of BOQ returned by the subcontractor, (4) preparation of schedules for the activities, (5) development of tender programme (6) taking off, (7) understanding construction technology and methods and (8) bidding strategies. Furthermore, the paper established the followings 
method of knowledge sharing practices in Nigerian construction firms. These are (1) face to face interaction, (2) site/ departmental meeting, (3) mentoring and tutoring, (4) project briefing and interviewing sessions and (5) internal training courses. Conclusively, the general level of knowledge sharing practices in Nigerian construction firms is at the infancy stage. Therefore, the paper recommended that the top management of Nigerian construction firms should adopt knowledge sharing practices to improve performance. The professional bodies should encourage the individuals to share their tacit knowledge to avoid the reinventing of the wheel. The construction activities that are commonly used to share knowledge should expand to accommodate all aspects of construction works, method and techniques. The management of construction firms should encourage the use of ICT in practice knowledge sharing to enhance the efficiency of the organizations.

\section{REFERENCES}

1. Alam, S. S., Abdullah, Z., Ishak, N. A., \& Zain, Z. M. (2009). Assessing Knowledge Sharing Behaviour among Employees in SMEs: An Empirical Study. International Business Research, 2(2). doi: 10.5539/ibr.v2n2p115

2. Babcock, P. (2004, May 1). Shedding light on knowledge management. HR Magazine, 49(5), 46-50.

3. Begoña, M.-F., \& Carmen, P.-S. (2011). Knowledge construction and knowledge sharing: a Wiki-based approach. Procedia - Social and Behavioral Sciences, 28, 622-627. doi: 10.1016/j.sbspro.2011.11.118

4. Bollinger, A. S., \& Smith, R. D. (2001). Managing organisational knowledge as a strategic asset. Journal of Knowledge Management, 5(1), 8-18.

5. Bresnen, M., Edelman, L., Newell, S., Scarbrough, H., \& Swan, J. (2003). Social practices and the management of knowledge in project environments. International Journal of Project Management, 21(3), 157-166. doi: 10.1016/s0263-7863(02)00090-x

6. Carrillo, P., Robinson, H., Al-Ghassani, A., \& Anumba, C. (2004). Knowledge Management in UK Construction: Strategies, Resources and Barriers. Project Management Journal, 35(1), 46-56. doi: $10.1177 / 875697280403500105$

7. Chen, J.-H. (2008). KNN based knowledge-sharing model for severe change order disputes in construction. Automation in Construction, 17(6), 773-779. doi: 10.1016/j.autcon.2008.02.005

8. Chen, Y.-H., Wu, J.-J., \& Chung, Y.-S. (2008). Cultural Impact on Trust: A Comparison of Virtual Communities in China, Hong Kong, and Taiwan. Journal of Global Information Technology Management, 11(1), 28-48. doi: 10.1080/1097198x.2008.10856460

9. Cheng, M. Y, Ho, S. Y, \& Lau, P. M. (2009). Knowledge sharing in academic institutions: a study of Multimedia University Malaysia. Electronic Journal of Knowledge Management, 7(3), 313-324.

10. Choi, J. (2012). A Knowledge Representation Model for Formalizing Subcontractors' Scheduling Process. Journal of Asian Architecture and Building Engineering, 11(2), 275-282. doi: 10.3130/jaabe.11.275

11. Creswell, J. W. (2003). Research design: qualitative, quantitative and mixed methods (2nd ed.). Thousand Oaks: Sage Publications.

12. Creswell, J. W., \& Tashakkori, A. (2007). Editorial: Developing Publishable Mixed Methods Manuscripts. Journal of Mixed Methods Research, 1(2), 107-111. doi: $10.1177 / 1558689806298644$

13. Davenport, T., \& Prusak, L. (2005). Working knowledge: How organisations manage what they know. Retrieved from https://www.researchgate.net/publication/229099904_Working_Knowledge_How_Organizatio ns_Manage_What_They_Know 
14. Dent, R. J., Montague, K. N. (2004). Benchmarking knowledge management practice in construction. London: CIRIA.

15. Egbu, C. (2006). Knowledge production and capabilities - their importance and challenges for construction organisations in China. Journal of Technology Management in China, 1(3), 304-321. doi: 10.1108/17468770610704967

16. Eriksson, P. E. (2013). Exploration and exploitation in project-based organizations: Development and diffusion of knowledge at different organizational levels in construction companies. International Journal of Project Management, 31(3), 333-341. doi: 10.1016/j.ijproman.2012.07.005

17. Fernie, S., Green, S. D., Weller, S. J., \& Newcombe, R. (2003). Knowledge sharing: context, confusion and controversy. International Journal of Project Management, 21(3), 177-187. doi: 10.1016/s0263-7863(02)00092-3

18. Fong, P. S. W., Chu, L. (2006). Exploratory study of knowledge sharing in contracting companies: a sociotechnical perspective. Journal of Construction Engineering and Management, 132(9), 928939.

19. Forcada, N., Casals, M., Fuertes, A., Gangolells, M., \& Roca, X. (2010). A web-based system for sharing and disseminating research results: The underground construction case study. Automation in Construction, 19(4), 458-474. doi: 10.1016/j.autcon.2009.12.018

20. Forcada, N., Fuertes, A., Gangolells, M., Casals, M., \& Macarulla, M. (2013). Knowledge management perceptions in construction and design companies. Automation in Construction, 29, 83-91. doi: 10.1016/j.autcon.2012.09.001

21. Harrigan, E. (2005). Tobin builds knowledge infrastructure. The Engineers Journal, 59(6), 1-10.

22. Hendriks, P. (1999). Why Share Knowledge? The Influence of ICT on the Motivation for Knowledge Sharing. Knowledge and Process Management, 6(2), 91-100. doi: 10.1002/(sici)10991441(199906)6:2\%3C91::aid-kpm54\%3E3.0.co;2-m

23. Hillebrandt, P. M. (2000). Economic theory and the construction industry (3rd ed.) Basingstoke: Macmillan.

24. Hillebrandt, P. M., \& Cannon, J. (1990). The modern construction firm. Basingstoke: Macmillan.

25. Hsu, I.-C. (2008). Knowledge sharing practices as a facilitating factor for improving organizational performance through human capital: A preliminary test. Expert Systems with Applications, 35(3), 1316-1326. doi: 10.1016/j.eswa.2007.08.012

26. Jackson, S. E., Chuang, C.-H., Harden, E. E., \& Jiang, Y. (n.d.). Toward Developing Human Resource Management Systems for Knowledge-Intensive Teamwork. Research in Personnel and Human Resources Management, 27-70. doi: 10.1016/s0742-7301(06)25002-3

27. Jacobsson, M., \& Wilson, T. L. (2012). The Construction Company Through the Lens of Service Management: Inferences From Sweden. Services Marketing Quarterly, 33(2), 155-176. doi: 10.1080/15332969.2012.662460

28. Jeong, K. S., Lu, S. L., Sexton, M. G. (2010). Good practice transfer within small construction specialist trade contractors. Retrieved from http://www.arcom.ac.uk/-docs/proceedings/ar2010-07690778_Jeong_Lu_and_Sexton.pdf

29. Johannessen, J.-A., Olsen, B., \& Olaisen, J. (1999). Aspects of innovation theory based on knowledgemanagement. International Journal of Information Management, 19(2), 121-139. doi: 10.1016/s0268-4012(99)00004-3

30. Kamara, J. M., Anumba, C. J., \& Carrillo, P. M. (2002). A CLEVER approach to selecting a knowledge management strategy. International Journal of Project Management, 20(3), 205-211. doi: 10.1016/s0263-7863(01)00070-9 
31. Kasimu, M. A., Roslan, A.\& Fadhlin, A. (2013). Knowledge Sharing Practices in Construction Organisation in Nigeria. International Journal of Engineering Research \& Technology, 1(2), 1-10.

32. Kasimu, M., Roslan, A., Fadhlin, A., Saba, A., Kabiru, M., Jibrin, I. (2014). The Influence of Technological Devices on Knowledge Sharing Practices in the Construction Organisations in Nigeria. International Journal of Advancement in Research \& Technology, 3(8), 141-150.

33. Kim, W. C., \& Mauborgne, R. (1998). Procedural justice, strategic decision making, and the knowledge economy. Strategic Management Journal, 19(4), 323-338.

34. Kivrak, S., Arslan, G., Dikmen, I., Birgonul, M. T. (2008). Capturing knowledge in construction projects: Knowledge platform for contractors. Journal of Management in Engineering, 24(2), 8795.

35. Lee, H., \& Choi, B. (2014). Knowledge Management Enablers, Processes, and Organizational Performance: An Integrative View and Empirical Examination. (2003). Journal of Management Information Systems, 20(1), 179-228. doi: 10.1080/07421222.2003.11045756

36. Lee, J.-N. (2001). The impact of knowledge sharing, organizational capability and partnership quality on IS outsourcing success. Information \& Management, 38(5), 323-335. doi: 10.1016/s0378-7206(00)00074-4

37. Leung, J. K. L., \& Fong, P. S. W. (2011). The power of stories in the construction industry: lessons from other domains. VINE, 41(4), 466-482. doi: 10.1108/03055721111188548

38. Lin, Y.-C., \& Lee, H.-Y. (2012). Developing project communities of practice-based knowledge management system in construction. Automation in Construction, 22, 422-432. doi: 10.1016/j.autcon.2011.10.004

39. Ma, Z., Qi, L., \& Wang, K. (2008). Knowledge sharing in Chinese construction project teams and its affecting factors. Chinese Management Studies, 2(2), 97-108. doi: 10.1108/17506140810882234

40. Magnini, V. P. (2008). Practicing effective knowledge sharing in international hotel joint ventures. International Journal of Hospitality Management, 27(2), 249-258. doi: 10.1016/j.ijhm.2007.07.015

41. Maqsood, T., Finegan, A., \& Walker, D. (2006). Applying project histories and project learning through knowledge management in an Australian construction company. The Learning Organization, 13(1), 80-95. doi: 10.1108/09696470610639149

42. Meso, P., \& Smith, R. (2000). A resource-based view of organizational knowledge management systems. Journal of Knowledge Management, 4(3), 224-234. doi: 10.1108/13673270010350020

43. Myers, D. (2017). Construction Economics: A New Approach (4th ed.). London: Routledge.

44. Nonaka, I., Takeuchi, H. (1995). The Knowledge-Creating Company: How Japanese Companies Create the Dynamics of Innovation. New York: Oxford University press.

45. Nordin, N. , Daud, N. , Osman, W. (2012). Knowledge Sharing Behaviour among Academic Staff at a Public Higher Education Institution in Malaysia. International Journal of Educational and Pedagogical Sciences, 6(12), 3415-3420.

46. Payne, J., (2004). Demystifying knowledge management. Retrieved from https://www.coursehero.com/file/14764290/KM-Guide/

47. Robinson, H. S., Carrillo, P. M., Anumba, C. J., \& Al-Ghassani, A. M. (2005). Knowledge management practices in large construction organisations. Engineering, Construction and Architectural Management, 12(5), 431-445. doi: 10.1108/09699980510627135

48. Runeson, G., \& skitmore, M. (1999). Tendering theory revisited. Construction Management and Economics, 17(3), 285-296. doi: 10.1080/014461999371493

49. Sadiq Sohail, M., \& Daud, S. (2009). Knowledge sharing in higher education institutions. VINE, 39(2), 125-142. doi: 10.1108/03055720910988841 
50. Scully, R., Khosrowshahi, F. (2011). Implementing the process of knowledge sharing for small construction consultant practices in Ireland. The Built \&Human Environment Review, 4(1), 45-58.

51. Senge, P. (1997). Sharing knowledge: The leader's role is key to a learning culture. Executive Excellence, 14(11), 17-18.

52. Sheehan, T., Poole, D., Lyttle, I., \& Egbu, C. O. (n.d.). Strategies and Business Case for Knowledge Management. Knowledge Management in Construction, 50-64. doi: 10.1002/9780470759554.ch4

53. Tserng, H. P., \& Chang, C.-H. (2008). Developing a project knowledge management framework for tunnel construction: lessons learned in Taiwan. Canadian Journal of Civil Engineering, 35(4), 333-348. doi: 10.1139/107-116 